\title{
How powerful political ties appropriate resources and how weaker organizations protect themselves: A case study from Indonesia
}

\author{
Marleen Dieleman ${ }^{1} \cdot$ Henky Widjaja $^{2}$ (D
}

Published online: 6 March 2018

(C) The Author(s) 2018. This article is an open access publication

\begin{abstract}
We advance the resource dependence literature on appropriation of organizational resources by powerful partners, focusing on political ties. Using a unique emerging market case of a venture with political ties, we advance theory by unpacking how political connections can hurt the organization by increasing the permeability of organizational boundaries. Our extensions highlight the crucial role of control mechanisms for politically connected organizations.
\end{abstract}

Keywords Organizational boundary $\cdot$ Resource dependence $\cdot$ Political ties $\cdot$ Permeability

Organizations commonly seek to create linkages with external parties to access key resources and opportunities (Hitt, Ahlstrom, Dacin, Levitas, \& Svobodina, 2004), especially in emerging economies (Ahlstrom, Young, Nair, \& Law, 2003). Yet these linkages also carry some costs and risks (Lin \& Si, 2010). Researchers employing resource dependence theory (RDT) in particular have shown that risks are prevalent when there is a power imbalance, as powerful partners may appropriate organizational resources (Casciaro \& Piskorski, 2005; Emerson, 1962; Gulati \& Singh, 1998; Pfeffer $\&$ Salancik, 1978). Although considerable research has advanced our knowledge of the conditions under which organizations seek partnerships (e.g., Hillman, Withers, \& Collins, 2009; Katila, Rosenberger, \& Eisenhardt, 2008), we know much less about the mechanisms by which powerful partners appropriate resources (Mellahi, Frynas,

Henky Widjaja

mangkasara01@yahoo.com

Marleen Dieleman

marleen@nus.edu.sg

1 National University of Singapore, 15 Kent Ridge Drive, Mochtar Riady Building 06-51,

Singapore 119245, Singapore

2 Leiden University, Steenschuur 25, 2311 ES Leiden, The Netherlands 
Sun, \& Siegel, 2016; Xia, 2011) and, in turn, how weaker organizations can seek to protect themselves (Katila et al., 2008). This is important as smaller firms increasingly enter new markets and must partner with larger (and sometimes) state linked partners creating relationships that need to be carefully managed (Young, Ahlstrom, Bruton, \& Rubanik, 2011).

How companies can protect themselves against appropriation is a relatively recent but important research topic within RDT, especially in the context of powerful political ties, an area where capture by powerful partners is particularly acute. Political ties link the organization to the government with potentially beneficial effects (Hillman, 2005), but they cannot be fully controlled and may create their own problems such the extraction of rents or derailing strategy (Fan, Wong, \& Li, 2007; Lin \& Si, 2010; Shleifer \& Vishny, 1994; Siegel, 2007; Sun, Hu, \& Hillman, 2016; Sun, Mellahi, \& Wright, 2012). A new generation of RDT research suggests this problem is particularly salient in emerging economies, where new ventures often need powerful political ties to acquire resources such as licenses to operate and build legitimacy, but this can yield a power imbalance that may stimulate appropriation of firm resources (Mellahi et al., 2016).

A few recent studies address the question how appropriation works. For instance, Sun et al. (2016) detailed how substantial shareholders colluded with political ties to expropriate minority shareholders, but they focus mostly on well-established publicly listed companies. Dieleman and Boddewyn (2012) investigated how large business groups buffer political ties as a defense mechanism, and argue that companies must carefully employ what they call boundary management strategies to prevent appropriation, but they limit their contribution to organizational design. Overall, insights on how powerful political partners go about appropriating resources are still limited, especially in new ventures. Extant research in this emerging area is still insufficient to achieve an integrated perspective on protecting organizations from their powerful co-opted political ties (Mellahi et al., 2016; Sun et al., 2016).

This paper adds an important piece of the puzzle by uncovering a new mechanism of appropriation in the context of new ventures with co-opted political ties. Mechanisms are seen as crucial for theorizing since they make up the "wheelwork of agency" (Davis \& Marquis, 2005), and, thus can help uncover how appropriation works. We present a detailed case study of an Indonesian biofuel plantation that both benefited and suffered from actions taken by a politically active family that was tasked with running it. We show that purposeful boundary blurring is a mechanism used by powerful political partners to entrench themselves and to move resources beyond the firm boundary. Our longitudinal design and in-depth ethnographic method allowed us to identify several key risks of engaging politically active directors. In addition, it illuminates a mechanism of appropriation whereby the political tie purposely obscured the organizational boundary to gain power, which subsequently enabled full use of the organization's resources for private and political gain. Our study also allowed us to observe defense mechanisms and reflect on their (limited) effectiveness.

In doing so, this paper makes three core contributions. First, it contributes to an emerging research stream in RDT on mechanisms of appropriation, by demonstrating an additional way powerful partners capture value from organizations. In particular, we theorize that powerful partners may seek to increase the permeability of organizational boundaries in order to appropriate resources. Second, this paper contributes to the 
empirical literature on political ties, which has hitherto mostly focused on whether and under what conditions political ties are beneficial, rather than on their subsequent management and downside. Third, this paper highlights practical implications for organizations that seek to protect themselves from appropriation by powerful politically connected partners. This is particularly relevant for organizations in countries known for rampant corruption, where organizations cannot succeed without some form of political connection, so that the challenge is not whether one should have political ties, but rather how they should be managed.

\section{Resource dependence theory}

RDT, originally developed by Pfeffer and Salancik (1978), and a continued source of inspiration for management scholars (Christensen, 1997; Hillman et al., 2009; Lux, Crook, \& Woehr, 2011; Wry, Cobb, \& Aldrich, 2013), highlights that organizations experience dependence as they need resources located outside the organization, and that influencing and responding to such external dependencies is a key task of management. Forming linkages with outside parties is a coping mechanism as these ties provide advice, information, access to resources and legitimacy (Pfeffer \& Salancik, 1978). The degree to which organizations engage in such boundary spanning activity depends on managerial preferences, but generally increases with environmental uncertainty (Leifer \& Huber, 1977; Santos \& Eisenhardt, 2005) and with a heavier dependence on external resources (Pfeffer \& Salancik, 1978).

However, as organizations and their partners exchange resources, the nature of the interaction depends on the relative power of the parties (Emerson, 1962; Pfeffer \& Salancik, 1978; Thompson, 1967) and their degree of dependence on each other (Casciaro \& Piskorski, 2005). Therefore, organizations with external ties face a risk of their partners appropriating their resources (Gulati \& Singh, 1998), necessitating controls, in particular in cases of power imbalance. Much of the earlier literature on this looked at antecedents of tie formation such as the opportunity to reduce competition; managing dependences on buyers or suppliers; or opportunities for diversification to reduce dependences, in particular focusing on situations such as mergers, joint ventures and co-optation of power-holders (see Davis \& Cobb, 2009; Hillman et al., 2009 for a review). Later extensions of resource dependence have advanced our understanding of the dynamic nature of dependencies (Hillman et al., 2009; Xia, 2011) and the defense mechanisms that organizations can build to deal with appropriation concerns after the tie-formation stage (Inkpen \& Currall, 2004; Kirsch, 1996). Research suggests that one way to deal with appropriation concerns is through careful management of organizational boundaries (Dieleman \& Boddewyn, 2012; Katila et al., 2008).

A crucial aspect of organizational boundaries is permeability, or the degree of organizational openness to the environment (Aldrich \& Herker, 1977; Colignon, 1986; Oliver, 1993). Permeability is needed to share resources, for instance through boundary spanning activities or connections, but it also has negative effects (Lin \& Si, 2010; Young, Peng, Ahlstrom, \& Bruton, 2003). These include possible interference in the organization, lesser autonomy and control, or limited opportunity to build a common sense of purpose (Oliver, 1993). The central RDT dilemma we are addressing in this paper is that greater dependence requires more permeability, but the presence of 
a powerful partner requires more controls and, hence, less permeability. Organization scholars have suggested that boundary strategies are not sufficiently understood, and called for more process-research on boundary phenomena to further clarify the dynamics of power and dependence (Santos \& Eisenhardt, 2005). We take this as an opportunity to investigate the role of organizational boundary permeability after ties with powerful partners have been formed.

\section{Political ties and appropriation}

One area where appropriation is a special concern is when organizations have close links with government, giving rise to a phenomenon of appropriation known as "the grabbing hand" (Shleifer \& Vishny, 1994). Political ties can be defined as "boundaryspanning personal and institutional linkages between firms and the constituent parts of public authorities" (Sun et al., 2012: 68).

Most empirical studies link an organization's political ties to performance, either having positive (e.g., Hillman, Zardkoohi, \& Bierman, 1999), negative (e.g., Hadani \& Schuler, 2013; Siegel, 2007), or contingent effects (e.g., Lux et al., 2011; Sun et al., 2012) as compared to organizations without them. The political ties literature further suggests that advantages of having political ties could be better performance (e.g., Hillman, 2005; Peng \& Luo, 2000), first-mover advantages (Frynas, Mellahi, \& Pigman, 2006), higher chances of a government bailout (Faccio, Masulis, \& McConnell, 2006), or lower costs of capital (Boubakri, Guedhami, Mishra, \& Saffar, 2012). Yet, we also know that political ties can derail firm strategy in various ways (e.g., Fan et al., 2007; Siegel, 2007). They may expropriate funds (Fan et al., 2007), become involved in corporate governance (Okhmatovskiy, 2010), demand bribes (Li, Yao, \& Ahlstrom, 2015; Shleifer \& Vishny, 1994), interfere with management (Ahlstrom, Bruton, \& Lui, 2000) or introduce diverging goals (Sun, Mellahi, \& Thun, 2010). Research finds that political ties are particularly salient in emerging economies (Faccio, 2006), where institutions may be weak and organizations substantially dependent on the government (Ahlstrom et al., 2003).

RDT, with its emphasis on power and influence, suggests that political connectedness is not merely a useful link to external resources, but a process of boundary spanning and dependence that plays out through linkages across permeable organizational boundaries. How appropriation by powerful partners happens in the context of politically connected organizations is not extensively addressed in the literature on political ties, although Dieleman and Boddewyn (2012) suggested that firms use organizational design to selectively open and close organizational boundaries to exclude co-opted political ties from internal processes and lessen the negative effects of political ties. However, till date there is little process-research that shows how boundary spanning becomes a contentious process with conflicting needs for more and less permeability that can be successfully exploited by political ties that seek to appropriate firm resources.

We build further on this new generation of RDT literature and explore the appropriation mechanism from the perspective of powerful political ties. A longitudinal, qualitative approach to generate new insights on the process of the grabbing hand (i.e., co-opted political ties diverting resources from organizations) is undertaken. In 
addition, we investigate the link between organizational permeability and appropriation and examine how the weaker organization can protect itself from an aggressive partner.

\section{Methods}

\section{Research design and case context}

A single-case study of a politically connected venture was carried out. Although single case studies may not be representative of larger firm populations, they can offer more insights into potential mechanisms of interest because focusing on one case allows for greater richness and contextualization. An in-depth study is especially relevant in the context of political ties, as connectedness processes are typically implicit unless one has direct access to the company and its management.

Most of the literature related to political ties has sought to identify merely the presence of political ties (e.g., as directors) and their effects without explicitly investigating the organizational mechanisms by which co-opted political ties interact with the organization. A case study such as ours is complementary, as it articulates how political ties may seek to appropriate an organization (Yin, 2003).

Although extreme cases such as this are relatively rare, that does not make them less relevant (Starbuck, 2009). Studying extreme rather than "average" cases is important (Andriani \& McKelvey, 2009), as such cases typically have a significant effect on organizations or society and on theory development (Dieleman, 2010). Perrow's famous study of the Three Mile Island nuclear accident (Perrow, 1981) serves as a noteworthy example of the relevance of extreme event studies. Aguinis and Edwards (2014) recently advocated the importance of paying attention to outliers in management research. Specifically, they argued that studying influential outliers, for instance by using qualitative research, has strong theory-building potential.

Our selected case is the Indonesian company Jatropha Plantation (JP), a bio-fuel plantation established in 2007. The value of political connections in Indonesia is well documented (Carney, Dieleman, \& Taussig, 2017; Fisman, 2001). It is common knowledge among scholars of Indonesian business that political ties are an integral part of the private sector (e.g., Robison \& Hadiz, 2004; Van Klinken \& Aspinall, 2011) and their management represents a key success factor for organizations (Dieleman \& Sachs, 2008).

In 2006, the Indonesian government issued the national biofuels development blueprint, which aimed to replace up to $10 \%$ of the national fossil fuel consumption with biofuels and create employment for 3.5 million people on 5.25 million hectares of unused land by 2010 (Priyanto, 2008). This blueprint was supported by various regulations, policies and subsidies such as a special credit program and an assured market through a minimum quota of 5\% biofuel content in oil sold by Pertamina, the state-owned oil company. In this blueprint and subsequent regulations, the government endorsed jatropha as the most suitable biofuel crop given its perceived contribution to wasteland rehabilitation and poverty reduction in marginal areas.

JP was established after the adoption of this blueprint by a prominent, politically connected business player at the national level. The actual operation of the venture was left to a local political family in South Sulawesi, who subsequently engaged about 
8,000 local small-holder farmers and a number of brokers to plant nearly 43 million trees on about 17,000 ha of land in 15 districts, with an approximate initial investment of US\$10 million. The venture experienced setbacks due to a variety of reasons that are explained later. It was reorganized in 2009 and subsequently liquidated in 2011.

This case study covers the lifespan of the venture. Its design embeds several levels of analysis relevant to our context, including analyses of the organization, its stakeholders, the broader business and economic environment, the political environment and the relevant players at both the regional and national levels.

\section{Data collection and analysis}

As is common in qualitative research projects, our data were derived from multiple sources, with a particular focus on obtaining information from informants through interviews and direct operational observations. The key stakeholders in this case were the company's management and staff, government officials, farmers and middlemen. The aim was to gather data on all these key players through interviews and secondary data to obtain a holistic view of this venture. In particular, our sources included 66 interviews with different stakeholders, participant observation, media articles related to the company and its owners during the period under review, company documentation and industry studies, and an ethnography of a jatropha-producing village associated with the biofuels venture. Table 1 provides an overview of all sources used and we explain these further below.

The collection of information from informants was conducted in two periods of field work in South Sulawesi. Informed consent was obtained from all individual

Table 1 Case database

\begin{tabular}{|c|c|}
\hline Type of source & Details \\
\hline Interviews & $\begin{array}{l}\text { Company former management and staff, including general manager, } \\
\text { administrative, technical, and a seeds collector (8); interview with Pt Perkasa } \\
\text { Capital project manager for JP (1); farmers who participated in the out-grower } \\
\text { program (24); village brokers (16); government officials at provincial level and } \\
\text { at } 3 \text { district levels (9); former consultants to the company, NGO, experts, other } \\
\text { firms (8) }\end{array}$ \\
\hline Ethnographic field study & $\begin{array}{l}\text { Field notes from two field studies in Moncongloe Bulu in the Maros District of } \\
\text { South Sulawesi in July-September } 2011 \text { and April-June } 2012\end{array}$ \\
\hline Media sources & $\begin{array}{l}\text { Retrieved } 40 \text { newspaper articles related to the company and its owners during } \\
\text { 2007-2011 from the following Indonesian media: } \\
\text { Jakarta Globe; Jakarta Post; Kompas Daily; Tribun Timur Daily; Fajar Daily; } \\
\text { Merdeka Daily; Liputan Kota Daily; Antara News }\end{array}$ \\
\hline $\begin{array}{l}\text { Company documentation } \\
\text { and industry reports }\end{array}$ & $\begin{array}{l}\text { Biofuel reports and blueprint } \\
\text { Relevant regulations and subsidies } \\
\text { Perkasa Holding annual reports (2006-2011) } \\
\text { Perkasa Plantations annual reports (2006-2011) } \\
\text { Winrock International: Research report on business opportunity scoping study } \\
\quad \text { on Jatropha Curcas Indonesia and Philippines (October 2010) } \\
\text { Jatropha Plantation business plan } \\
\text { Sample contract with out-grower farmers }\end{array}$ \\
\hline Books & Erwiyantoro (2011). Dosa-Dosa Abdul Arief. Jakarta: Galang Press \\
\hline
\end{tabular}


participants included in the study. The first fieldwork was conducted from June 2011 to January 2012, while the second one was from April 2012 to September 2012. In addition to that, interviews were also organized in Jakarta with respondents from the national office of the company. Throughout the field work we interviewed former company management, including the key political tie holding the top management role in the venture, staff and consultants, government officials, former company middlemen and farmers who participated in the out-grower scheme of the company. The interviews were semi-structured and covered a wide range of informants. They were taped and transcribed. In addition to the formal interviews, we directly observed the company's operations in the office and field.

The interviews were conducted using the snowball method. ${ }^{1}$ We first interviewed the former company management and staff to get insights into the management of this venture. We covered the general managers, assistants, administration executives, technical agronomy personnel, and a seeds collector/community mobilizer. We then expanded the interviews to cover former company consultants, who provided further insights. To cover the political side of our story we interviewed government officials from the plantation offices at the provincial and district level (Maros, Gowa and Jeneponto), and former out-growers (i.e., farmers contracted by a company to produce a crop) and village brokers. A separate interview was conducted with a former jatropha investment project director of PT Perkasa Capital Indonesia, to provide us with information on the reason why the Perkasa Group entrusted the management of the venture to Arief, who was known as a politically connected party in the province. We also conducted information gathering and cross-checking of the company's story with other companies who interacted with the company and who were also active in similar ventures (one supplied seedlings to the company), as well as one non-governmental organization (NGO) with a project in the area that issued a report on jatropha that covered our venture. The number of interviewees grew as we asked the respondents to refer to other people who could be potential respondents. One of the authors also spent time at the company chatting casually with workers and in the field observing operations and interacting with traders, consultants, farmers, local political and government leaders and others.

The whole process allowed us to understand the perceptions and thinking processes of key actors through intense immersion and interaction. The length of the field work allowed us to position our research within the local political and economic context and to obtain in-depth insights into the management of the company and its local networks.

The primary data collection was also supported by the collection and analysis of secondary data. Media articles were systematically retrieved from the electronic databases of both national and local news websites based on searches of the company name and the names of associated people. This helped us to understand the position of key politicians, who were occasionally cited in relationship to the venture.

As it was a privately held company, documentation was difficult to obtain. However, we used the annual reports of the parent company and obtained a business plan in addition to sample contracts with farmers. In addition, we obtained documentation

\footnotetext{
${ }^{1}$ Snowball sampling is a common method in qualitative research which uses "a small pool of initial informants to nominate other participants who meet the eligibility criteria for a study" (Morgan, 2008). This method was appropriate for our research purpose as it allowed us to build up a considerable pool of informants in a setting where people were commonly connected to one another, and who would have otherwise been hard to locate.
} 
related to the economic and legal environments in the forms of industry studies, policy papers and relevant regulations.

The case study was part of a more extensive international research program related to jatropha in Indonesia, which represented most of the jatropha activity from various academic disciplines (e.g., agronomy, anthropology and legal studies) during the same period. This broader research program helped us interpret our case within the broader context of jatropha in Indonesia as we could compare our case with other jatropha ventures.

There was no strict distinction between data collection and analysis as themes emerged. We iterated back and forth between interpretation and data collection (e.g., Glaser \& Strauss, 1967) and continuously tried to triangulate the sources to see where convergence and divergence of opinion occurred. Once a comprehensive picture of the company's operations and networks had emerged from the data and no substantial new information became available, we realized that the key theme was the somewhat ambivalent effect of the organization's political networks.

We subsequently embarked on a more rigorous investigation of our rich case database to articulate the mechanisms that determined the fuzzy interactions between the company and political parties during the company's lifetime. To do so, we made lists of the key players at different levels (i.e., company management, company staff, advisors, farmers, middlemen/brokers, local government officials) and the key events for the company (genesis, outreach, organizational design, mixing politics and business, and venture liquidation), and outlined the boundary spanning processes and drivers that were supported by our data. We present these processes in more detail in the following sections.

Our study involves agents of considerable prominence, power and notoriety in Indonesia. The nature of the discoveries we made raised a debate over whether to disclose the real company and actor names. After considering various arguments, we decided to make the protection of the respondents and researchers our highest priority, and to disguise the names of the relevant people, companies, organizations and political parties involved.

\section{Case narrative}

\section{Jatropha plantation (JP) genesis and key players}

PT Jarak Pagar, later renamed PT Jatropha Plantation (hereafter: JP), was established in 2007 in South Sulawesi Province as a jatropha biofuel plantation company. Its immediate parent company was PT Perkasa Capital Indonesia, a unit of the Perkasa Group. A special department within Perkasa Capital dealt with high-risk new investments, provided funding, drafted business plans in consultation with experts, and monitored progress toward expected financial returns (we interviewed the Perkasa Project Director in charge). JP was a relatively small new venture in the context of the large business group.

The new company started with a comprehensive business plan that covered upstream activities (nurseries and planting) to downstream activities (Jatropha oil production and trade). In the business plan, JP had an organizational structure in which the 
offices in each kabupaten (district) would coordinate nurseries and out-grower farmers, procure harvests and produce jatropha crude oil, which would then be transported to the city of Makassar for processing into biofuel and distribution to buyers. The design involved the company contracting with farmers, who would become members of cooperatives. Like all new plantation ventures in Indonesia, critical issues were land, local permits, and good relationships with local farmers and communities, all of which required local connections.

Fortunately, the Perkasa Group was one of the best-connected business groups in the country. Fauzie Perkasa, the patriarch of the group, was among Indonesia's wealthiest and served as Minister from 2005 to 2009, Chairman of the Civic Party (a disguised name for one of the largest political parties in Indonesia) from 2009 to 2014, and Chair of the National Team for Biofuels Development from 2006 to 2009. According to the Forbes wealthiest Indonesians list Perkasa's wealth was at a peak in the period 2007-2009, when the venture was established, and declined thereafter. In 2012, he was declared the official 2014 Indonesian presidential candidate for the Civic Party.

Given Fauzie Perkasa's leading role in the Civic Party, it was not surprising that the Perkasa Group tapped on Civil Party networks to ensure the success of JP. Abdul Arief, a senior Civic Party politician from South Sulawesi, was given operational responsibility for the new jatropha biofuel plantation venture. Arief was a member of parliament for the Civic Party from 1999 to 2004 and thereafter served as a senior national chairman. In 2009, he was appointed as the special elections coordinator for Eastern Indonesia (to which Sulawesi island belonged), allowing him to approve candidates for legislative and executive positions. Within South Sulawesi province he played an important role as a patron to many local Civic Party politicians (Buehler, 2013; Buehler \& Tan, 2007). The Civic Party dominated the government in South Sulawesi and was the best-organized political party during the period of this research, its networks reaching out from urban political elites down to the village level, in particular to farmers and civil servants (Buehler, 2007; Noor, 2010).

Arief was also known as a national "cooperatives" figure, having led various organizations such as the Indonesian Cooperative Council. He was also involved in his own business ventures, for instance the trading of commodities such as cloves, sugar, cooking oil and rice, using cooperatives. In 2005, he was sentenced to 2.5 years in jail for violating customs regulations for rice imports. He was released in 2006 .

In the same year, PT Perkasa Capital Indonesia commissioned a feasibility study for a jatropha plantation in West Nusa Tenggara Province, where most of the jatropha activity was centered. One JP executive we interviewed explained that the investment was finally moved to South Sulawesi after Arief succeeded in convincing Fauzie Perkasa that JP would be more successful in South Sulawesi under his strong political influence. Local political ties were important, as JP's success relied on local government permits and support, as well as on large numbers of local farmers to grow the crop. The JP general manager interviewed for this study recalled:

JP's presence and success was due to the role of Abdul. It was he who lobbied and convinced the Perkasa Group to invest in South Sulawesi. His influence and network allowed the company to receive support from local government. 


\section{Venture outreach}

After JP's establishment by the Perkasa Group which provided key resources and financing, and the involvement of Abdul Arief, the powerful local political tie, the venture started to reach out to farmers. Extensive nursery plots and out-grower schemes were established in 15 districts of South Sulawesi with a total coverage of 17,040 ha. About 8,000 farmers were recruited and provided with various cash and in-kind incentives totaling approximately 3 million rupiah (about US\$300) per hectare. These were considered loans. In return, the farmers had to submit photocopies of their land titles as proof of participation. The 25-year out-grower contract specified that the loan would be repaid in the form of jatropha seeds for 5 years with the land as collateral.

JP's rapid success in recruiting so many out-grower farmers can be credited to the Arief connection. The interviews and observations indicated that the Arief family mobilized the Civic Party network and their familial network with key people in every district. One former JP out-grower manager stated:

Important positions belonged to those who had family connections with or were close relatives of the Arief family. This included families of district heads who were under the Civic Party. Abdul also assigned his allies [...]. In districts such as Bone and Bulukumba, the recruitment was massive because the family was very influential in those areas.

Abdul Arief also decided to involve his family members in the company. JP's management was dominated by Arief's siblings, with Ali Arief as Director, Ibrahim Arief as General Manager and other Ariefs in various strategic managerial positions (the Arief brothers held various political positions in the Civic Party and other political parties, and had their own business ventures, so their involvement in JP was not full time).

JP's operations relied mostly on local resources. Key agronomy advisors and technical field staff were sourced from two universities in South Sulawesi, even if there was not any prior experience with jatropha in the province. The company employed so-called out-grower staff to convince farmers to join. Local elites such as the Bupatis (district heads) and their families, politics cadres, village and hamlet heads, school teachers and many others became field organizers, especially for the purpose of recruiting farmers. The timing of the venture was favorable, as it coincided with a sharp fall in the price of cocoa, a crop commonly farmed in the area.

A newly established sister company owned by Kadir Arief, another brother of Abdul Arief, became the sole provider of logistics services, including agro-inputs and transportation. The JP office building also housed other Arief family businesses belonging to the brothers. Altogether, this extensive involvement of Arief's siblings blurred the boundary between JP and the Arief family's other activities. The Ariefs appeared to treat JP as part of the family's politico-business activities, something not uncommon in Indonesia (Robison \& Hadiz, 2004).

The Ariefs were not famous for their business experience, especially in plantations. After a year, a shift occurred in the company, including a name change from PT Jarak Pagar to PT Jatropha Plantation. One former staff member said in an interview that the 
change occurred because Fauzie Perkasa did not feel at ease knowing that JP was publicly known as an "Arief company" under its previous name. Furthermore, the interviewees suggested that representatives from Perkasa Capital deemed it necessary to intervene in the company's management by assigning several experienced plantation professionals to supervise the management team. Although this caused considerable tension in the office, a former company executive revealed they had limited authority and effect:

We had the representatives of Perkasa. They were professionals from Perkasa Plantation [a listed plantation company] and also retirees from PTPN [a stateowned plantation company]. But they could not do much. They had their own room in the office but did not have a good relationship with the Ariefs. They were completely isolated.

Despite the management's impressive land coverage claims (the venture would have been the largest jatropha plantation in Indonesia), the actual planted area turned out to be far less. According to informants, the claims were based on the total land certificate copies collected by the out-grower staff. However, our ethnographic study revealed that farmers did not actually plant this area, rather it was simply their total land holdings. The overstatements occurred because the performance targets and financial incentives of JP's out-grower staff were based on land coverage. Moreover, the nursery units pushed the out-grower staff to find areas to plant the seedlings they produced. In short, the implementation of the out-grower scheme did not comply with standard practice to obtain original land certificates as collateral. By accepting copies of land certificates and not checking planting activity properly, JP disbursed cash as loans that were guaranteed by fictitious collateral. The interviews suggested that this occurred because the Ariefs lacked professional qualifications as plantation managers and performance assessment and oversight was poor. Different assessment routines and measurement play a big role in what resources get allocated or legitimized by the public or government (Dunbar \& Ahlstrom, 1995; Garud \& Ahlstrom, 1997). Poor assessment routines can be particularly harmful to newer ventures seeking to legitimacy (Ahlstrom, Bruton, \& Yeh, 2008). In this respect, a former agronomy advisor stated:

If we refer to the reputation of Perkasa Group as a professional and experienced investor in plantations, where they have PT Perkasa Plantations, a professional plantation company, it is impossible for them to make basic mistakes like what happened in JP. [...] The management was very poor and far from what a professional plantation company would do.

\section{Organization design and dependence}

According to one advisor, JP failed because of its out-grower model, which was uncommon for Indonesian plantations. In one interview, a former agronomy advisor claimed that instead of the out-grower scheme, he had proposed a more common "nucleus out-grower model" in which the company would have its own "nucleus" plantation of 50 ha per kabupaten (district) in addition to the out-growers. This 
would have decreased the company's dependence on farmers and secured a minimum raw material supply, and the plantation could have been used as a model to attract out-grower farmers. However, his proposal was rejected by the Perkasa management:

I proposed the nucleus out-grower scheme. I advised JP to establish a nucleus first before asking farmers to join as out-growers. [...] But when the proposal was taken to Jakarta, it came back totally different. Perkasa decided to establish outgrowers without a nucleus.

Why did the Perkasa Group apply the full out-grower scheme despite it being uncommon for plantations in Indonesia? Although there were special programs, which mandated the involvement of smallholders through farmer groups or cooperatives as a condition for obtaining credit, these did not require organizations to engage in a $100 \%$ out-grower model. The Ariefs probably convinced Perkasa Capital that they would bring in farmer support through the Civic Party's networks so that the company need not buy and clear land, and could instead rely on existing farmers to scale up the venture rapidly. As Katila et al. (2008) argued, accessing external resources is especially attractive for new ventures that seek to scale quickly. This model, inevitably, also made JP more dependent on Abdul Arief, who was the key person able to mobilize the farmers through his political networks in the province.

Driven by land coverage targets, JP's staff did not perform proper verification of the land committed for jatropha and failed to collect the original land certificates from the farmers. The farmers submitted copies because they were promised cash for every planted jatropha tree plus fertilizer and herbicide incentives. The larger the area, the more incentives they would receive. Also, the cash was disbursed before farmers signed the contract.

The interviews and direct field observations showed that the farmers used most of their land for food and cash crops instead. Although jatropha was supposed to grow even on marginal land, we found that even the most infertile lands were actually planted with drought-resistant crops such as cassava, timber and fruit trees. Our ethnographic study revealed that many out-grower farmers did not plant the seedlings, but hid or destroyed them and provided misleading information to the company about fake plantation activity in remote places that the JP staff was unlikely to visit. The field interviews suggested that only $25 \%$ of the total reported area was really planted with jatropha, despite management's claim that it was $40 \%$.

\section{Mixing politics and business}

The massive recruitment of farmers was in turn favorable for the Civic Party. JP's operational period coincided with elections at the national and sub-national levels, with Abdul Arief assigned to lead the "winning team" for the Civic Party in South Sulawesi. This made JP more attractive to Arief as resource to tap on in order to win elections, a phenomenon also observed in other studies on resource dependence. For instance, a study of Vale in Brazil suggested that dependence relations between company and political ties shifted during election periods, when the government sought to interfere and expropriate company resources (Rodrigues \& Dieleman, 2018). 
Our data (interviews, news articles) agree that the large-scale recruitment of and cash disbursements to farmers were used to gather votes. One example is the 2008 gubernatorial election, where the Civic Part candidate used the positive image of jatropha ("a solution to rural poverty") and the availability of credit to farmers as tools to mobilize votes. One former field organizer recalled:

Farmers were confused about the cash incentives. They considered the money as a free token since it was paid to them at the time of the JP launch by the Governor. They did not know that it was only an advance. They then were reluctant to join the contract when they realized that it was a loan and they were required to commit their lands for a long-term contract. This misperception happened because the field staff was not honest to farmers about the matter, and it was paid prior to the distribution of seedlings and the establishment of a formal contract agreement.

However, the link between JP and politics also had unintended negative consequences for the venture. As other studies show, being affiliated with one political tie can pose real risks when the political climate shifts (Fisman, 2001). For example, one government official in Gowa District interviewed for this study said that the political element in JP turned him off "Their investment was used to promote one candidate... Of course, we in the Gowa government did not like it because we support [the opponent]."

Our findings show that the Arief family did not just use the venture's resources to promote Civic Party candidates, but also for other purposes. One of the Arief brothers mobilized company resources in his bid to become Chair of the National Progress Party in South Sulawesi (a disguised name for another prominent political party in Indonesia). One local newspaper wrote:

It was written on the signboard that the event was for PT Jatropha Plantation, but the participants were mostly district chairmen of the National Progress Party in South Sulawesi. There were 21 branches in attendance at the event, which appeared to be the declaration of Ali Arief as the candidate for the provincial chairman position (Fajar Daily: May 13, 2010).

After succeeding, Ali Arief went on to use the JP office as the provincial secretariat of the National Progress Party, with a "National Progress Party Provincial Office" signboard appearing in front of the JP office building. His brother, Ibrahim Arief, was the party secretary. In part by using company resources, the Arief family came to control multiple political parties, thus gaining even more in power.

It appeared that the physical use of the JP building for all sorts of Arief activities was symbolic for the confusing flows of resources, people and information in and out of JP, which RDT predicts are problematic as they may lead to the organization being out of control (Oliver, 1993). We discovered large-scale corruption in the venture operations from the management level down to the farmer level. Our informants alleged that the extensive recruitment of out-growers was used to justify excessive spending on procurement, handled by the affiliated company owned by one of the Arief brothers (who was also the vice chairman of the Civic Party in South Sulawesi). 
The interviews also provided evidence of corruption related to the disbursement of credit to farmers by field organizers in collusion with management, using the total land claims as a basis. We did not find much evidence of tight control of activities by Perkasa Capital.

The use of JP for politics and the negative profile of the Arief family had a significant effect on farmers' perceptions of and behavior toward the company:

We know who [broker name] is. He always comes to us with his projects that are never sustainable. So how can we expect jatropha to succeed? We only know from him that JP will pay incentives to those who participate, and that was our main reason to join.

The ethnographic study provided evidence that the brokers exploited the farmers and stimulated them to cheat. The cash intended for the farmers was embezzled and the outgrower data were falsified. The brokers were also rather explicit with the farmers about their short-term goals, and taught the farmers how to cheat the company. In short, by mixing politics and business, the powerful political tie in JP virtually erased the boundary between JP, the company, and local politics, and they appropriated its resources for other purposes. Key external stakeholders, including farmers, were left confused about JP's commercial purpose, and were even encouraged to appropriate resources themselves in the absence of proper oversight.

\section{Venture liquidation}

After operating at a large scale for two years, the ultimate owner Perkasa Capital commissioned an audit that resulted in a decision to stop field activities and resize the company in 2009 , leaving only a group of staff members working on the financial settlement between JP and Perkasa Capital. JP remained idle until February 2011, when the Perkasa Group finally decided to dissolve it.

Our field interviews suggested that unprofessional and corrupt management and an excessive use of the venture as a political vehicle led to the Perkasa Group audit in 2009. According to informants, Fauzie Perkasa was disappointed with the careless implementation, which led to widespread appropriation of JP's resources. However, no effort to follow up was made after the audit, such as an investigation into the fictitious collateral documents and the Arief family's (mis)use of organization assets. Instead, the venture was silenced. To our knowledge, JP's failure had no further ramifications for any of the cheating stakeholders.

JP was the biggest jatropha investment implemented in Indonesia. According to interviews with management and local journalists, approximately 100 billion rupiah (US\$10 million at 2013 exchange rates) was spent, mostly on out-growers, personnel and investments in properties. The suspension of the venture coincided with the end of the jatropha hype and the global failure of jatropha as a biofuel due to unpredictable yields making the crop economically unviable. JP's management adopted this rationale in explaining the venture's failure, with one of the Arief brothers saying in an interview that it failed "because of the unclear market for both jatropha seeds and the oil."

According to management, no significant jatropha seed trade was realized, as the low market price hampered plans to purchase jatropha seeds from farmers. JP only 
occasionally purchased seeds in small quantities. We found no evidence that the company processed seeds into biofuel. There was clearly a problem with the basic business model of jatropha. Other smaller jatropha ventures in Indonesia also had limited effect, and some were associated with fraud. Vel et al. (2013) provided an overview of all jatropha activity in Indonesia, which suggests that the appropriation of company resources on this scale was unique to JP, which chose to co-opt a powerful political tie without instating proper defense or control mechanisms.

\section{Summary and interpretation}

In the previous section, we presented our data as a condensed narrative. In this section, we summarize and interpret the case in the light of dynamic mutual dependence and appropriation by political ties. Table 2 illustrates the link between case narrative and theoretical constructs.

We interpret JP and the Civic Party (which controlled the local government) as primary entities, connected through a co-opted political tie (Abdul Arief). Our case immediately problematizes "the organization," "the Civic Party" and "the political tie" as unitary actors with fixed boundaries and simple goals. Our in-depth ethnography revealed how all actors in this case were embedded in larger networks and had multiple roles and conflicting goals.

We perceive the organization and the local Civic Party as interdependent (Emerson, 1962), and Table 2 illustrates how venture and political party influenced each other through the political tie. Perkasa chose to co-opt Arief to gain access to the local resources of the Civic Party, a common response to managing organizational dependencies on external actors such as local governments (Pfeffer \& Salancik, 1978), in particular for new ventures (Katila et al., 2008). Abdul Arief immediately introduced multiple family members into the organization and pro-actively involved and recruited political networks as employees and contractors, as well as participating farmers, in particular those associated with the Civic Party. We argue that this made the organization boundary more permeable, as resources, people and information seemed to move across its boundaries freely. Colignon (1986) suggested that the multiplicity of linkages that characterizes permeable boundaries also induces a variety of communication mechanisms that results in information being dispersed more rapidly. This high level of organizational boundary permeability helped to reach out to crucial stakeholders (in particular: farmers with access to land) and to achieve scale in a short period. In order to benefit from external resources, there must be some openness of organizational boundaries (Oliver, 1993).

However, JP was quite weak and poorly monitored, whereas Arief was powerful locally, thus introducing a power imbalance. Further, the mutual dependencies changed as the partnership progressed, as predicted by RDT (Hillman et al., 2009). The business model adopted relied on farmers who were loyal to the local tie. Civic Party networks and farmers were stimulated by "free money." The "free" money in turn helped the Civic Party to secure votes from farmers and brokers, and it justified the Civic Party's claim of "rural poverty alleviation." At the same time, this model also entrenched the tie and decreased the owner's power over the local political family, which eventually led to the venture's demise (along with an unfeasible business model). Pfeffer and Salancik 


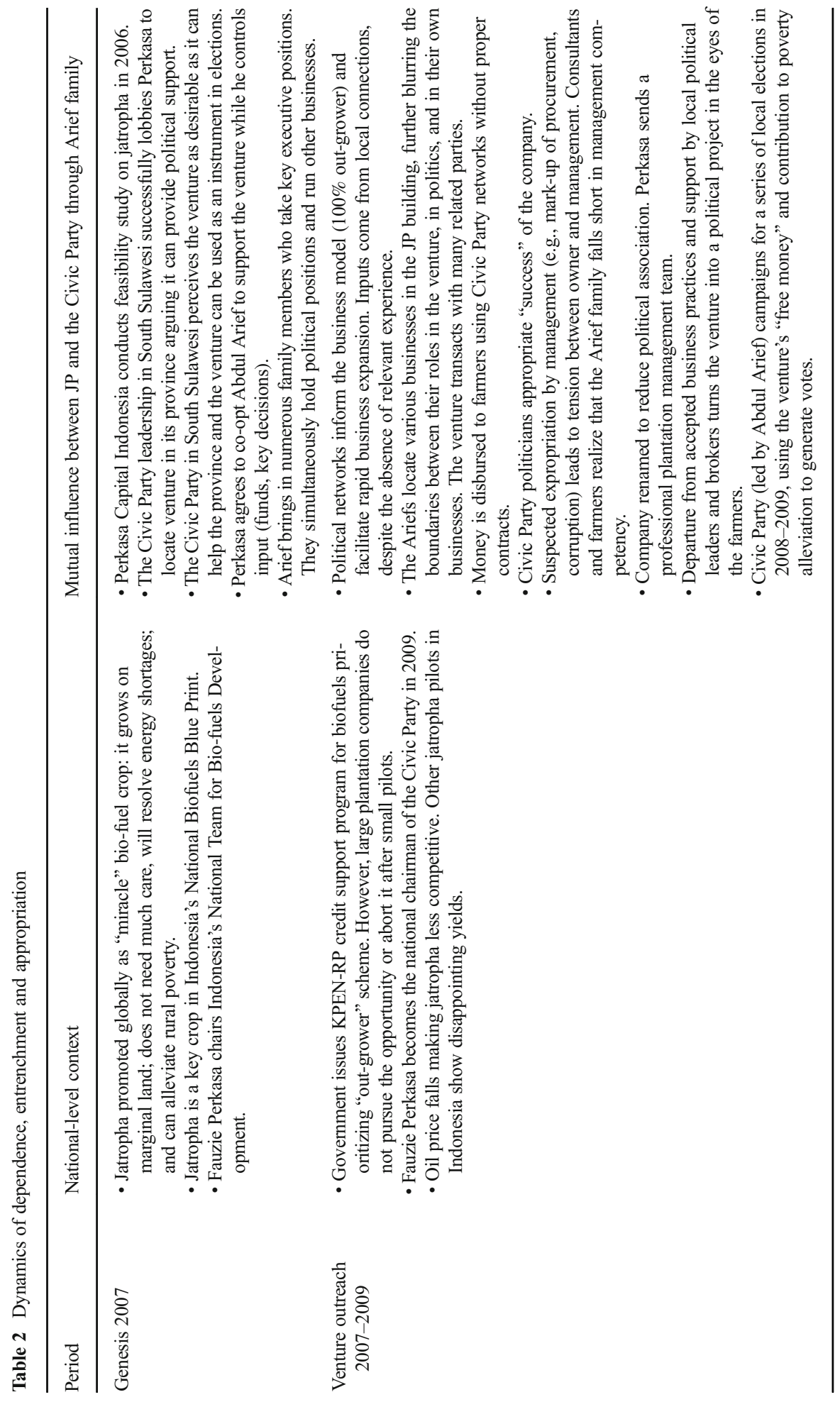




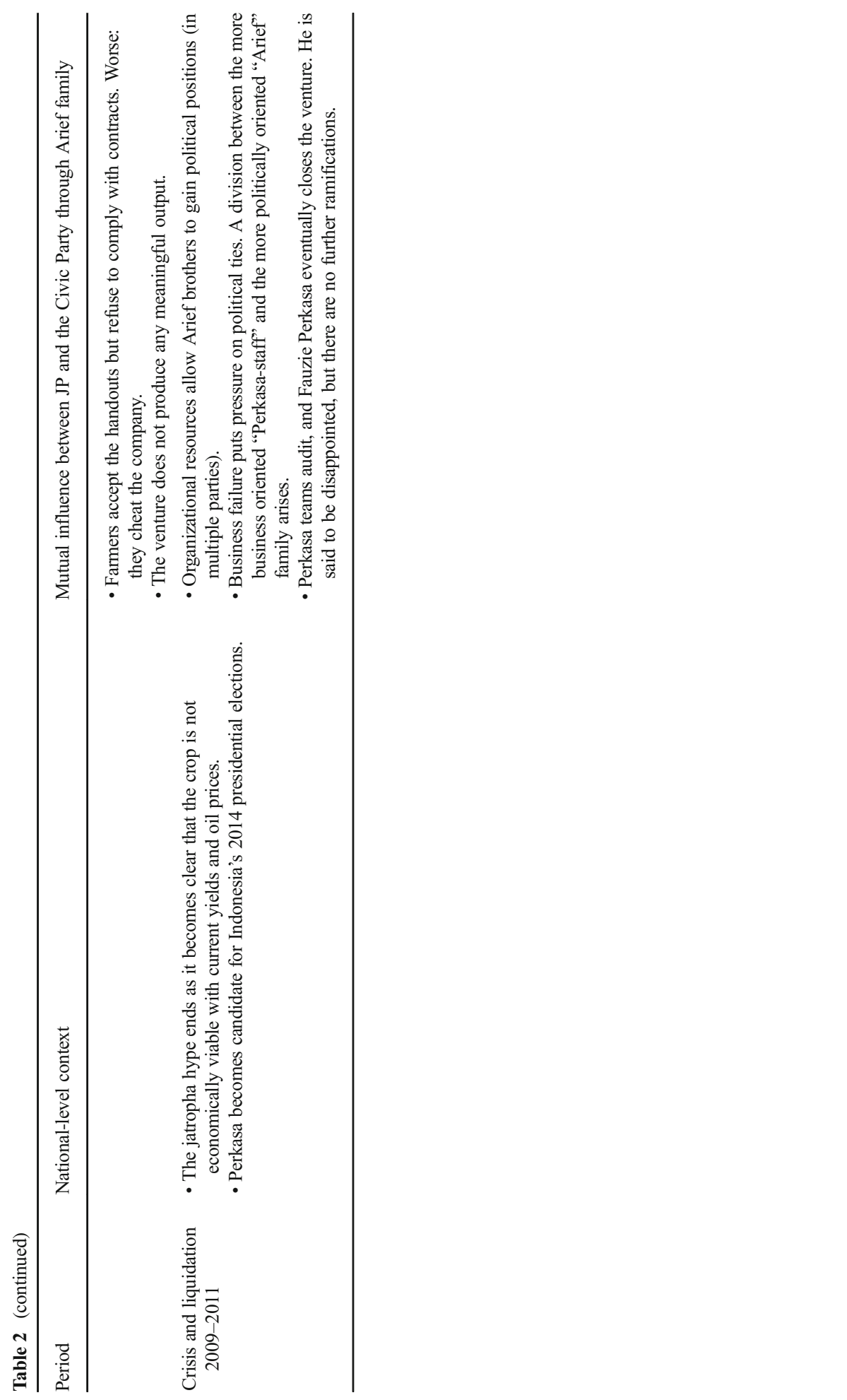


(1978) suggested that companies may look for alternative providers of the resource in situations of dependence. However, in our particular case, alternative providers of the critical resource (local political support) were not abundant. Perkasa's leadership of the Civic Party at the national level limited his partner substitution options, as the current political tie was the leading family within his party in South Sulawesi province.

In line with earlier process-research related to mutually dependent partners (e.g., Das \& Teng, 2002; Koza \& Lewin, 1998), we observed dynamics that changed the nature of the venture, the partners, their interests, the influence they had over one another, and the boundaries of the organization - in other words, the actors co-evolved. For instance, the Civic Party received a boost in votes through the venture, the Ariefs used the venture to increase their local political power, and the venture incorporated Civic Party networks within its boundaries. This is in line with other studies on firm-political co-evolution (e.g., Dieleman \& Sachs, 2008; Van Klinken \& Aspinall, 2011).

Not only did we find dynamics going back and forth between PT Jatropha Plantation and the Civic Party, we also found that these dynamics rapidly spiraled out of control, exacerbating its downfall. The co-opted political tie (i.e., Arief) engineered a permeable boundary, which RDT suggests is important to exchange valuable resources (e.g., Oliver, 1993). This ensured the local government and PT Jatropha Plantation were mutually reinforcing (in the early stage), leading to rapid scaling in the mobilization of farmers through existing political patronage networks. No other jatropha venture reached this scale in Indonesia. However, the company subsequently experienced a downward spiral once incompetence, corruption and political use of its assets became more blatant and spread from the organization to its stakeholders, even if the owner, the Perkasa Group, belatedly tried to intervene.

Through the actions of the political tie the organization became absorbed within the local political domain, with the co-opted tie becoming more entrenched, an interesting observation which the literature on "grabbing hands" (e.g., Fan et al., 2007) has not yet explored. The most telling example was that field organizers acted based on the assumption that the organization was a "political" venture, and they not only siphoned off funds but also encouraged farmers to do the same, thus accelerating the spiral of corruption and further politicizing the business, causing the organization, with its permeable boundaries and extensive resource exchange, to descend into a situation of widespread corruption (Lange, 2008).

\section{Protecting organizational boundaries}

This case occurred in a developing country where organizations depend significantly on the goodwill of politicians and the government. Full constraint absorption when dealing with a dependence on government is not possible, and the question for most organizations is not whether to co-opt political ties, but rather how to handle such interactions (i.e., boundary management). Thus, it is important to re-direct our attention to the question of which defense mechanism organizations can use to handle political ties.

Elaborate studies of control in organizations have distinguished between input, process and output controls and between formal and informal controls (e.g., Kirsch, 1996; Lange, 2008). In our particular case, some formal attempts were made to maintain control and alter the organizational design, such as by sending more 
professional plantation management or changing the name of the organization. The venture did not seem to have consciously used boundaries as a defense mechanism, as observed by Dieleman and Boddewyn (2012) in another Indonesian case of a connected venture. However, formal design change attempts were made only after problems became evident, and their effect was limited, we argue because the tie engineered a very high level of permeability making control difficult. In this case, as predicted by Dieleman and Boddewyn (2012), formal controls would have been more effective at the initial stages of the venture. Had the owner sent professional plantation management from the very beginning and relegated Arief to a non-executive role, the business model adopted probably would not have relied entirely on farmers, the access to which depended on the Ariefs, resulting in greater entrenchment. By appointing Abdul Arief in an executive role and by allowing so many of his brothers to hold key positions, the boundary between organization and family was made extremely permeable. For instance, most of the inputs were procured locally from one brother, and the office building gave the impression that it housed all of the Arief businesses.

The owner attempted to limit the permeability symbolically by changing the name of the entity and eventually by closing it quietly when the desired output was not achieved. The actions of the Arief brothers influenced the prevailing perception of JP's organizational boundaries: the organization was part of the Arief family, and the venture's primary aim was politics. According to an interview with the Jakarta-based Perkasa Group manager responsible for the project, the Perkasa Group controlled access to funds (i.e., inputs) and they monitored outputs. These are all common control strategies to prevent corruption (e.g., Lange, 2008). However, we found very little evidence of process-based controls at the local level (Lange, 2008). Had the Perkasa Group insisted on more control over the interaction between organization, political parties, government officials, and farmers from the outset, such as through better financial and operational oversight rather than ex-post auditing, the spread of corruption from the organization to field organizers and farmers might not have gotten out of hand.

While the venture became Indonesia's largest jatropha investment, the capital invested was rather insignificant compared with the overall size of the Perkasa Group, which helps explain the limited process controls placed on the venture's management. While closing the venture was probably the right business decision given the price of oil and disappointing yields, more control would have limited the losses. Furthermore, there was a danger of the venture causing reputational damage to the owner, who had declared himself a presidential candidate. The fact that no action was taken to recover missing funds or formally investigate the local political tie may be explained by the fact that the Perkasa and Arief families were engaged in repeated partnerships at multiple levels, and thus the venture's closure was a delicate matter.

Based on our case study, we suggest that when political ties are co-opted, these ties may use purposeful boundary-blurring as a mechanism of appropriation. In this case it occurred by mixing political networks and business through intensive exchanges across permeable organizational boundaries, whereby organizational resources were siphoned off and stakeholders even started to perceive the business as an integral part of local politics. Therefore, organizations must pay attention to organizational control mechanisms, similar to the process of designing and managing mutual dependences in joint ventures or alliances (e.g., Kumar \& Seth, 1998; Xia, 2011). With respect to our second 
question, namely how organizations can prevent resource appropriation by powerful partners, our results show that additional organizational design choices (e.g., limiting the role of the tie) and process choices (e.g., maintaining control over the tie's actions across organization boundaries) are essential. Our case clearly suggests it is difficult to protect boundaries once they have become blurred, or to shift mutual dependencies once a tie has become entrenched. In the context of co-opted political ties, we suggest process-based controls are especially important in regulating the interaction between a tie and other stakeholders beyond the organization boundary to prevent the escalation of undesired interference.

\section{Robustness-Alternative explanations}

We now consider some alternative explanations. Using an ethnographic study meant deep immersion in the research context and an acute awareness that each actor was entangled in multiple networks and had multiple, often conflicting goals. Our study is a plausible interpretation of a complex reality, based on careful analysis and comparison of multiple sources. However, other explanations may also be plausible. The Perkasas could have used the venture simply for political handouts, for vote gathering, or as a "compensation" for prior services rendered by the Ariefs, although our interviews and data did not support this (e.g., the Ariefs started mixing the venture with other political parties). The venture would probably have failed anyway, and the negative effect of political ties was only one factor contributing to its downfall, so that we may attribute too much weight to this in our interpretation (although our interviews highlighted the importance of the organization's entanglement with local political networks). Even if our dependence dynamics do not solely explain the venture's failure, they nevertheless demonstrate the argument that political connections coupled with open boundaries can have disproportional negative effects (e.g., money outflows and loss of legitimacy).

As such, our study redirects attention beyond formal organizational design variables (e.g., whether a political tie is co-opted as a director or shareholder) that is typical of much of the literature on political ties, toward process controls to regulate interactions across permeable organizational boundaries. Insufficient boundary management may increase the negative effects of powerful political ties on which an organization depends.

\section{Discussion}

\section{Contributions}

In response to the limited knowledge on how political ties, once co-opted, may hurt companies, we studied an Indonesian venture which highlighted the dynamics of mutual dependencies in organizations with co-opted political ties. The extreme nature of our study enabled us to elicit patterns of appropriation, and the single case design allowed us to interpret organizational design within the specific context of the venture and the local political setting. Ethnographies are well suited to investigate the complex motivations of actors, and to disentangle causalities going in multiple directions. All of 
the actors in this case had multiple goals at any one time, and therefore the failure to reach a goal (e.g., start up a successful business) might have positively contributed to another goal (e.g., gathering votes from farmers). Our case also demonstrates complex dynamics over time as dependencies shifted and the organization became more entangled in local politics and corruption. As such it vividly showcases the doubleedged sword of permeable boundaries and the need for appropriate organizational defense mechanisms to shield organizations from the negative effects of their political ties.

Our contribution is threefold. First, we contribute to RDT by combining the original insights of RDT, notably those articulated by Pfeffer and Salancik (1978) and refined by others (see Wry et al., 2013) on the dynamics of dependence and power, with insights on boundary permeability (e.g., Colignon, 1986; Oliver, 1993). We suggest that higher dependence on powerful partners presents a dilemma in that it requires permeability to allow for resource exchange, but also opens the organization to risks of lower control and appropriation by powerful actors (Mellahi et al., 2016). It is suggested that powerful partners deliberately try to increase permeability to facilitate entrenchment and appropriation. In our particular case, the political partner drew familial and political networks into the organization and used resources to benefit them, thus tying the organization to politics and corruption. By illuminating this boundary-blurring mechanism, we generate important insights on defense mechanisms to counter it, in particular limiting the powers of the tie through organizational design, and instituting more process controls on resource movement across boundaries. These insights move beyond defenses already known in the literature, such as secrecy (Katila et al., 2008), and more powerful independent directors and oversight (Sun et al., 2016).

Second, we contribute to the political ties literature, which has generally focused more on the presence and merit of political ties rather than their subsequent management (Sun et al., 2012). We advance a mechanism that explains what managerial choices may exacerbate negative effects of co-opted political ties. Our explanation suggests that co-opted political ties purposely blur organizational boundaries to entrench themselves and may then use the organization's resources for political and private gain. Our work opens up an important new line of inquiry on defense mechanisms available to organizations when handling co-opted political ties, and suggests that RDT insights on appropriation and boundaries (e.g., Dieleman \& Boddewyn, 2012; Katila et al., 2008) offer a fruitful starting point to further extend our knowledge on the management of political ties.

Last, we contribute to practice as our case study contains valuable insights on how firms can manage their political ties. We have suggested that organizations need to carefully manage their boundaries when co-opting political ties, similar to joint ventures and alliances, taking into account that the power balance might shift in the partner's favor. Although an open organizational boundary is needed to access resources on which the organization depends, it is necessary to implement controls through organizational design (i.e., limit how much executive power a political tie has) as well as process controls to mitigate the potentially negative impact from a "grabbing hand" (i.e., control who the political ties brings in, direct control over transactions with outside parties, ensure the identity of the organization is not mixed with politics). 


\section{Limitations and further research}

Our study also has several limitations, which offer opportunities for future research. First, our findings are certainly context specific. It was not entirely surprising to find this extreme case in a new industry with no established players. Risks are higher in entirely novel industries, which only "fools" rush to enter, according to Aldrich and Fiol (1994), with untested products and business models. Furthermore, in new markets situated in weak institutional environments failure is easier to justify and fraud easier to disguise (Ahlstrom, Young, \& Nair, 2002; Peng, Ahlstrom, Carraher, \& Shi, 2017). A new government-subsidized industry faces additional complexities, as it introduces public goals (in this case, poverty alleviation and the use of lower-quality land) that organizations incorporate into their business models but that may not be sustainable. Studies of larger samples across different industries and countries could shed more light on the boundary conditions of the mechanisms advanced.

Moreover, corruption pervades our case study, and this calls for further investigation, both empirically and conceptually. It also requires interpretation within the Indonesian context, where networks linking politics with business are both resilient and adaptable, especially at the local level (Van Klinken \& Aspinall, 2011: 140). In this study, we were interested in politically connected organizations, which is broader than just corruption (Li et al., 2015). We suggest that the untangling of political ties, organizational boundaries and corruption is another fruitful line of inquiry that could yield additional insights (Ahlstrom et al., 2003).

In addition, in our proposed mechanism, we assumed that the degree of boundaryspanning interaction and dependence mattered for the likelihood that resource appropriation would occur. However, the kind of interaction between organization and coopted political tie might also have mattered. Had the co-opted political tie acted in a bona fide way, the case might have evolved differently. Without a control group or comparative study such counterfactual "what-if" questions cannot be answered through our single case design (McCloskey, 1987). Hence, we believe that eliciting the types of interactions organizations have with co-opted political ties is a fruitful area for future inquiry.

Overall, we believe our study opens up opportunities for future research, which we hope will explore in more detail how firm boundaries can be protected from appropriation by powerful partners, in particular co-opted political ties. We hope to generate more interest in the management of political ties and suggest that process-research can be a useful lens to do this. Such research can have practical import (Abrahamson, 2008) given the extensive role that governments and state linked organizations play in today's commerce.

\section{Conclusion}

This paper has addressed the mechanisms by which powerful co-opted political ties appropriate resources from an organization, and how can weaker organizations are able to protect themselves. RDT suggests that permeable organizational boundaries are needed to access crucial resources that lie outside the firm, but 
open boundaries between the organization and its environment also lead to risks. We detail an extreme case study of a politically connected venture that illustrates this phenomenon. The venture, a jatropha plantation in Eastern Indonesia in the biofuel industry, was managed by a key political tie, who incorporated familial and political networks into the company. Although this initially helped to scale the venture, it also shifted the power balance, entangling the venture with politics in the eyes of stakeholders. The political tie ensured frequent movements of resources and information across organizational boundaries, and the rapidly escalating cheating by internal and external stakeholders, combined with poor market circumstances, led to the venture's liquidation.

Our main insight is that political ties may deliberately pursue permeable organizational boundaries to shift dependence dynamics in their favor and to appropriate resources, which in turn highlights the crucial role of control mechanisms, including organizational design choices and process controls that manage and regulate resource exchange across organizational boundaries.

By employing RDT, and outlining a new mechanism of appropriation through an in-depth qualitative ethnographic study, our attention can be redirected to the management of political ties on which the organization depends and which also affect (and limit) key strategic avenues open to firms, particularly in emerging economies (Wang, Ahlstrom, Nair, \& Hang, 2008). As such, we hope this case helps to stimulate and guide future research on co-optation of political ties. We suggest that RDT offers opportunities for further advancement in understanding the negative effects of political ties, and we add to RDT by clarifying that boundary permeability can be used as a mechanism for appropriation. We highlight important strategic questions that organizations face when handling dependence on governments and politicians, including organizational design choices, boundary management and process controls.

Our take-away message from this study is that new ventures in emerging economies that decide to co-opt political ties need to make careful choices on how to control the exchange of resources across organizational boundaries so as to reap the benefits of networking while managing the costs (Ahlstrom \& Bruton, 2006). For instance, limiting the executive power of the political tie; controlling who the political partner brings into the firm; and monitoring transactions with external parties can help to minimize the perception that the organization is little more than a political vehicle. Although open boundaries are needed to benefit from political ties, too much permeability may lead to organizational resource appropriation, or worse. Without carefully designed control mechanisms the risks of co-opting powerful political ties to manage external dependences may exceed the benefits. It is important to emphasize that firms may need to hire locally connected individuals, perhaps those associated with local or regional government (Ahlstrom et al., 2000). But at the same time, our research shows the further importance of understanding the multiple motivations of these political ties. Coopted political ties are valuable precisely because of their connections, but these may invariably come with loyalties that do not coincide with the interests and intentions of your firm. Proper control mechanisms and monitoring are key to the avoidance of problems associated with coopting powerful political partners in new ventures in emerging economies. 
Acknowledgements The authors participated in the research cluster "Jarak: the commoditization of an alternative biofuel crop in Indonesia" under the "Agriculture beyond Food" program, and gratefully acknowledge funding by the Royal Netherlands Academy of Sciences (KNAW), the Netherlands Organization for Scientific Research (NWO) and the Royal Netherlands Institute of Southeast Asian and Caribbean Studies (KITLV).

Open Access This article is distributed under the terms of the Creative Commons Attribution 4.0 International License (http://creativecommons.org/licenses/by/4.0/), which permits unrestricted use, distribution, and reproduction in any medium, provided you give appropriate credit to the original author(s) and the source, provide a link to the Creative Commons license, and indicate if changes were made.

\section{References}

Abrahamson, E. 2008. 22 things I hate mini rants on management research. Journal of Management Inquiry, 17(4): 422-425.

Aguinis, H., \& Edwards, J. R. 2014. Methodological wishes for the next decade and how to make wishes come true. Journal of Management Studies, 51(1): 143-174.

Ahlstrom, D., \& Bruton, G. D. 2006. Venture capital in emerging economies: Networks and institutional change. Entrepreneurship theory and practice, 30(2): 299-320.

Ahlstrom, D., Bruton, G. D., \& Lui, S. S. 2000. Navigating China's changing economy: Strategies for private firms. Business Horizons, 43(1): 5-15.

Ahlstrom, D., Bruton, G. D., \& Yeh, K. S. 2008. Private firms in China: Building legitimacy in an emerging economy. Journal of World Business, 43(4): 385-399.

Ahlstrom, D., Young, M. N., \& Nair, A. 2002. Deceptive managerial practices in China: Strategies for foreign firms. Business Horizons, 45(6): 49-59.

Ahlstrom, D., Young, M. N., Nair, A., \& Law, P. 2003. Managing the institutional environment: Challenges for foreign firms in post WTO China. SAM Advanced Management Journal, 68(2): 41-49.

Aldrich, H., \& Fiol, M. 1994. Fools rush in? The institutional context of new industry creation. Academy of Management Review, 19(4): 645-670.

Aldrich, H., \& Herker, D. 1977. Boundary spanning roles and organization structure. Academy of Management Review, 2(2): 217-230.

Andriani, P., \& McKelvey, B. 2009. From Gaussian to Paretian thinking: Causes and implications of power laws in organizations. Organizational Science, 20(6): 1053-1071.

Boubakri, N., Guedhami, O., Mishra, D., \& Saffar, W. 2012. Political connections and the cost of capital. Journal of Corporate Finance, 18: 541-559.

Buehler, M. 2007. Local elite reconfiguration in post-new order Indonesia: The 2005 election of district government heads in South Sulawesi. Review of Indonesian and Malaysian Affairs, 41(1): 119-147.

Buehler, M. 2013. Married with children. Inside Indonesia: 116. http://www.insideindonesia.org/featureeditions/married-with-children, Accessed Nov. 28, 2017.

Buehler, M., \& Tan, P. 2007. Party-candidate relationship in Indonesian local politics: A case study of the 2005 regional election in Gowa, South Sulawesi Province. Indonesia, 84: 41-69.

Carney, M., Dieleman, M., \& Taussig, M. 2017. How are institutional capabilities transferred across borders?. Journal of World Business, 51: 882-894.

Casciaro, T., \& Piskorski, M. J. 2005. Power imbalance, mutual dependence and constraint absorption: A closer look at resource dependence theory. Administrative Science Quarterly, 50: 167-199.

Christensen, C. M. 1997. The innovator's dilemma: When new technologies cause great firms to fail. Boston: Harvard Business School Press.

Colignon, R. 1986. Organizational permeability in U.S. social service agencies. Organization Studies, 8(2): 169-186.

Das, T. K., \& Teng, B. S. 2002. The dynamics of alliance conditions in the alliance development process. Journal of Management Studies, 39(5): 725-746.

Davis, G. F., \& Cobb, A. J. 2009. Resource dependence theory: Past and future. In C. B. Schoonhoven, \& F. Dobbin (Eds.). Stanford's organization theory renaissance, 1970-2000: Research in the sociology of organizations: 21-42. Bradford: Emerald Group.

Davis, G. F., \& Marquis, C. 2005. Prospects for organization theory in the early twenty-first century: Institutional fields and mechanisms. Organization Science, 16(4): 332-343.

Dieleman, M. 2010. Shock-imprinting: External shocks and ethnic Chinese business groups in Indonesia. Asia Pacific Journal of Management, 27(3): 481-502. 
Dieleman, M., \& Boddewyn, J. 2012. Using organization structure to buffer political ties in emerging markets: A case study. Organization Studies, 33: 71-95.

Dieleman, M., \& Sachs, W. M. 2008. Coevolution of institutions and corporations in emerging economies: How the Salim Group morphed into an institution of Suharto's crony regime. Journal of Management Studies, 45(7): 1274-1300.

Dunbar, R. L., \& Ahlstrom, D. 1995. Seeking the institutional balance of power: Avoiding the power of a balanced view. Academy of Management Review, 20(1): 171-192.

Emerson, R. M. 1962. Power-dependence relations. American Sociological Review, 27: 31-40.

Erwiyantoro. 2011. Dosa-Dosa Nurdin Halid. Jakarta: Galang Press.

Faccio, M. 2006. Politically connected firms. American Economic Review, 96: 369-386.

Faccio, M., Masulis, R. W., \& McConnell, J. 2006. Political connections and corporate bailouts. Journal of Finance, 61(6): 2597-2635.

Fan, J. P. H., Wong, T. J., \& Li, T. 2007. Politically-connected CEOs, corporate governance and post-IPO performance of China's newly partially privatized firms. Journal of Financial Economics, 84(2): 330-357.

Fisman, R. 2001. Estimating the value of political connections. American Economic Review, 91(4): 1095-1102.

Frynas, J. G., Mellahi, K., \& Pigman, G. A. 2006. First mover advantages in international business and firmspecific political resources. Strategic Management Journal, 27(4): 321-345.

Garud, R., \& Ahlstrom, D. 1997. Technology assessment: A socio-cognitive perspective. Journal of Engineering and Technology Management, 14(1): 25-48.

Glaser, B. G., \& Strauss, A. L. 1967. Strategies for qualitative research. Chicago: Aldine.

Gulati, R., \& Singh, H. 1998. The architecture of cooperation: Managing coordination costs and appropriation concerns in strategic alliances. Administrative Science Quarterly, 43: 781-814.

Hadani, M., \& Schuler, D. A. 2013. In search of El Dorado: The elusive financial returns on corporate political investments. Strategic Management Journal, 34(2): 165-181.

Hillman, A. J. 2005. Politicians on the board of directors: Do connections affect the bottom line?. Journal of Management, 3(3): 464-481.

Hillman, A. J., Zardkoohi, A., \& Bierman, L. 1999. Corporate political strategies and firm performance: Indications of firm-specific benefits from personal service in the US government. Strategic Management Journal, 20(1): 67-81.

Hillman, A. J., Withers, M., \& Collins, B. J. 2009. Resource dependence theory: A review. Journal of Management, 35: 1404-1427.

Hitt, M. A., Ahlstrom, D., Dacin, M. T., Levitas, E., \& Svobodina, L. 2004. The institutional effects on strategic alliance partner selection in transition economies: China vs. Russia. Organization Science, 15(2): 173-185.

Inkpen, A. C., \& Currall, S. C. 2004. The coevolution of trust, control, and learning in joint ventures. Organizational Science, 15(5): 586-599.

Katila, R., Rosenberger, J. D., \& Eisenhardt, K. 2008. Swimming with sharks: Technology ventures, defense mechanisms, and corporate relationships. Administrative Science Quarterly, 53: 295-332.

Kirsch, L. J. 1996. The management of complex tasks in organizations: Controlling the systems development process. Organizational Science, 7(1): 1-21.

Koza, M. P., \& Lewin, A. Y. 1998. The co-evolution of strategic alliances. Organizational Science, 9(3): $255-264$.

Kumar, S., \& Seth, A. 1998. The design of coordination and control systems in managing joint venture-parent relationships. Strategic Management Journal, 19: 579-599.

Lange, D. 2008. A multidimensional conceptualization of organizational corruption control. Academic Management Review, 33: 710-729.

Leifer, R., \& Huber, G. P. 1977. Relations among perceived environmental uncertainty, organizational structure, and boundary spanning behavior. Administrative Science Quarterly, 22(2): 235-247.

Li, Y., Yao, F. K., \& Ahlstrom, D. 2015. The social dilemma of bribery in emerging economies: A dynamic model of emotion, social value, and institutional uncertainty. Asia Pacific Journal of Management, 32(2): 311-334.

Lin, J., \& Si, S. X. 2010. Can guanxi be a problem? Contexts, ties, and some unfavorable consequences of social capital in China. Asia Pacific Journal of Management, 27(3): 561-581.

Lux, S., Crook, T. R., \& Woehr, D. 2011. Mixing business with politics: A meta-analysis of the antecedents and outcomes of corporate political activity. Journal of Management, 5: 169-187.

McCloskey, D. N. 1987. Counterfactuals. In J. Eatwell, M. Millgate, \& P. Newman (Eds.). The new Palgrave: A dictionary of economic theory and doctrine: 95-97. London: Macmillan.

Mellahi, K., Frynas, J. G., Sun, P., \& Siegel, D. 2016. Review of the nonmarket strategy literature: Toward a multi-theoretical integration. Journal of Management, 42(1): 143-173.

Morgan, D. L. 2008. Snowball sampling. In L. M. Given (Ed.). The Sage encyclopedia of qualitative research methods: 816-817. Thousand Oaks: Sage. 
Noor, F. A. 2010. Mapping the religious and secular parties in South Sulawesi and Tanah Toraja, Sulawesi, Indonesia. RSIS working paper no. 213, Nanyang Technological University, Singapore.

Okhmatovskiy, I. 2010. Performance implications of ties to the government and SOEs: A political embeddedness perspective. Journal of Management Studies, 47(6): 1020-1047.

Oliver, C. 1993. Organizational boundaries: Definitions, functions, properties. Canadian Journal Administrative Sciences, 10(1): 1-16.

Peng, M. W., Ahlstrom, D., Carraher, S. M., \& Shi, W. 2017. An institution-based view of global IPR history. Journal of International Business Studies, 48(7): 893-907.

Peng, M. W., \& Luo, Y. 2000. Managerial ties and firm performance in a transition economy: The nature of a micro-macro link. Academic Management Journal, 43(3): 486-501.

Perrow, C. 1981. Normal accident at Three Mile Island. Society, 18(5): 17-26.

Pfeffer, J., \& Salancik, G. R. 1978. The external control of organizations: A resource dependence perspective. New York: Harper \& Row.

Priyanto, U. 2008. The policy of biofuel in Indonesia. BPPT Indonesia: Power Point Presentation.

Robison, R., \& Hadiz, V. R. 2004. Reorganising power in Indonesia: The politics of oligarchy in an age of markets. London: Routledge.

Rodrigues, S. B., \& Dieleman, M. 2018. The internationalization paradox: Untangling dependence in multinational state hybrids. Journal of World Business, 53(1): 39-51.

Santos, F. M., \& Eisenhardt, K. M. 2005. Organizational boundaries and theories of organization. Organizational Science, 16: 491-508.

Shleifer, A., \& Vishny, R. 1994. Politicians and firms. Quarterly Journal Economics, 109: 995-1025.

Siegel, J. 2007. Contingent political capital and international alliances: Evidence from South Korea. Administrative Science Quarterly, 52(4): 621-666.

Starbuck, W. H. 2009. Cognitive reactions to rare events: Perceptions, uncertainty, and learning. Organization Science, 20(5): 925-937.

Sun, P., Hu, H. W., \& Hillman, A. J. 2016. The dark side of board political capital: Enabling blockholder rent appropriation. Academy of Management Journal, 59(5): 1801-1822.

Sun, P., Mellahi, K., \& Thun, E. 2010. The dynamic value of MNE political embeddedness: The case of the Chinese automobile industry. Journal of International Business Studies, 41: 1161-1182.

Sun, P., Mellahi, K., \& Wright, M. 2012. The contingent value of corporate political ties. Academic Management Perspectives, 26: 68-82.

Thompson, J. D. 1967. Organizations in action. New York: McGraw Hill.

Van Klinken, G., \& Aspinall, E. 2011. Building relations: Corruption, competition and cooperation in the construction industry. In E. Aspinall, \& G. Van Klinken (Eds.). The state and illegality in Indonesia: 139164. Leiden: KITLV Press.

Vel, J., Simandjuntak, D., van Rooijen, L., Widjaja, H., Affiff, S., van Klinken, Z. G., Tjeuw, J., Slingerland, M., Semedi, P., Shulte Nordholt, H., Persoon, G., Otto, J. M., Suharsono, S., Snelder, D., Orij, R., Dieleman, M., Bedner, A., \& McCarthy, J. 2013. Jatropha: From an iconic biofuel crop to a green-policy parasite. IIAS Newsletter, 66: 15.

Wang, L. C., Ahlstrom, D., Nair, A., \& Hang, R. Z. 2008. Creating globally competitive and innovative products: China's next Olympic challenge. SAM Advanced Management Journal, 73(3): 4-15.

Wry, T. E., Cobb, J. A., \& Aldrich, H. E. 2013. More than a metaphor: Assessing the historical legacy of resource dependence and its contemporary promise as a theory of environmental complexity. Academy of Management Annals, 7(1): 441-449.

Xia, J. 2011. Mutual dependence, partner substitutability, and repeated partnership: The survival of crossborder alliances. Strategic Management Journal, 32(3): 229-253.

Yin, R. 2003. Case study research: Design and methods, 3rd ed. Beverly Hills: Sage.

Young, M. N., Ahlstrom, D., Bruton, G. D., \& Rubanik, Y. 2011. What do firms from transition economies want from their strategic alliance partners? Business Horizons, 54(2): 163-174.

Young, M. N., Peng, M. W., Ahlstrom, D., \& Bruton, G. D. 2003. Principal-principal agency. Web Journal of Chinese Management Review, 6(1): 18-45.

Marleen Dieleman (PhD, Leiden University) is an Associate Professor of strategy and family business at NUS Business School in Singapore. Her research focuses on business groups in Asia.

Henky Widjaja is a $\mathrm{PhD}$ student at Leiden University. His interests are in regional development and political affairs in Indonesia. 